\title{
Original Studies
}

\section{Applicability of Percutaneous Transluminal Coronary Angioplasty to Patients With Recombinant Tissue Plasminogen Activator Mediated Thrombolysis}

\author{
Eric J. Topol, MD, Jaan E. Eha, MD, Kenneth P. Brin, MD, \\ Edward P. Shapiro, MD, James L. Weiss, MD, Mary B. Riegel, RN, \\ Sidney O. Gottlieb, MD, and Jeffrey A. Brinker, MD
}

\begin{abstract}
To test the utility and safety of percutaneous transluminal coronary angioplasty (PTCA) after recombinant tissue plasminogen activator (t-PA), we performed the procedure in all suitable candidates with acute myocardial infarction (MI) who had successful t-PA mediated coronary thrombolysis. Twenty consecutive patients with $M I$ received $t-P A$ after coronary angiographic conformation of total occlusion. Successful recanalization with t-PA was achieved in 13 patients, leaving a residual obstruction of $84 \pm 6 \%$ in the nine patients for whom PTCA was attempted at a mean of $21.6 \mathrm{~h}$. Success was achieved in seven patients, leading to a residual lesion of 29 $\pm 7 \%$. In the two patients for whom PTCA was unsuccessful, total reocclusion occurred prior to the attempt despite therapy with heparin, aspirin, dipyridamole, and nifedipine. All PTCA procedures were uncomplicated. Serial two-dimensional echocardiography at 10 days, compared to admission, demonstrated infarct zone wall motion index improvement in the patients with successful PTCA (group A, 0.83 \pm 0.36 to $1.46 \pm 0.49$ ) as compared to the 13 patients without thrombolysis or successful PTCA (group B, $0.61 \pm 0.26$ to $0.66 \pm 0.39),(P<0.05)$. One patient of group A sustained a massive stroke at 2 weeks after hospital discharge. In the remaining six patients, follow-up exercise testing and/or coronary arteriography demonstrated a negative treadmill test and/or patent infarct vessel, respectively. After successful PTCA, no patient had clinical signs of reocclusion, reinfarction, postinfarction angina, or congestive heart failure. At $9.4 \pm 2$ months, all six patients are asymptomatic and have returned to work. Thus, sequential PTCA after t-PA can
\end{abstract}

From the Johns Hopkins Hospital and Francis Scott Key Medical Center, Baltimore.

This study was supported by Ischemic Heart Disease SCOR grant 2P50-HL-17655 from the National Heart, Lung, and Blood Institute, Bethesda, Maryland and Genentech, Inc., South San Francisco, California. The study was presented in part at the 34th Scientific Sessions of the American College of Cardiology, Anaheim, California, March 1985.

Dr. Topol is now at the Cardiac Study Unit, S5438 Main Hospital, University of Michigan Hospital, 1405 E. Ann St., Ann Arbor, MI 48109.

Address reprint requests to Jeffrey A. Brinker, MD, 501 CMSC, The Johns Hopkins Hospital, 600 N. Wolfe St., Baltimore, MD 21205.

Received February 12, 1985; revision accepted May 12, 1985.

(C) 1985 Alan R. Liss, Inc. 
be performed safely and successfully in patients with MI and this approach may be associated with improved regional function and a favorable post-MI course.

Key words: coronary angioplasty, coronary thrombolysis, acute myocardial infarction, regional myocardial function

\section{INTRODUCTION}

Since the widespread acceptance of the high frequency and importance of total coronary artery occlusion in the early phase of acute myocardial infarction, various therapeutic strategies have been proposed. Recanalization of the infarct vessel with streptokinase, either by intracoronary or intravenous delivery, has been the most common method utilized to date [1-10]. However, several placebo controlled studies have not shown clear-cut benefit for patients in terms of recovery of left ventricular function $[2,4,6,9]$. With streptokinase administration, no matter which route is selected, there is attendant fibrinogenolysis and a prolonged lytic state [11-13]. With the introduction of human tissue-type plasminogen activator, produced by recombinant technology, an enzyme with a short half-life $(<5 \mathrm{~min})[14,15]$ and relative fibrin selectivity has become available [16-23].

Besides thrombolytic therapy, percutaneous transluminal coronary angioplasty (PTCA), either directly or after streptokinase, has been performed in the setting of acute myocardial infarction and various studies point toward the potential advantage of this technique in promoting more complete and sustained infarct vessel recanalization [24-34]. The current study was undertaken to determine the safety, feasibility, and outcome of combined therapy with t-PA and PTCA in patients with acute myocardial infarction.

\section{MATERIALS AND METHODS}

\section{Patient Selection}

As part of a multicenter pilot trial of t-PA in acute myocardial infarction [18], patients who presented to either The Johns Hopkins Hospital or the Francis Scott Key Medical Center with chest pain of greater than 20 min but less than $6 \mathrm{~h}$ duration and associated with $\geqslant 1 \mathrm{~mm}$ of electrocardiographic ST segment elevation (in one or more leads) were considered for entry to the protocol. The exclusion criteria were cardiogenic shock, history of a bleeding diathesis, coronary artery bypass surgery or transmural myocardial infarction, age $>70$ years, and significant hepatic, renal, and pulmonary disease.

\section{Angiography and Thrombolysis}

Once the above criteria were met, informed consent was obtained. The study protocol was approved by the institutional review boards of both hospitals. Patients underwent selective coronary arteriography, both of the infarct vessel and the noninfarct related arteries, using the Judkins technique. After arterial access was obtained, heparin $(100 \mathrm{U} / \mathrm{kg}$, maximum $10,000 \mathrm{U})$ was administered. Coronary angiograms were obtained in both right and left oblique projections as well as multiple hemiaxial views. Total occlusion of the infarct vessel was confirmed in 21 of 34 patients initially 
entered into the study. According to the study design, only those patients with total occlusion were candidates for t-PA therapy.For the first 16 patients entered, there was two to one randomization between t-PA and placebo. In the placebo arm of the study, if no recanalization was observed after $30 \mathrm{~min}$ of serial angiography (angiograms were performed every $15 \mathrm{~min}$ after the start of study drug to $2 \mathrm{hr}$ ), patients were crossed over to intracoronary t-PA $(0.375 \mathrm{mg} / \mathrm{kg}$ over $15-30 \mathrm{~min})$. Patients initially randomized to $t-P A$ received this enzyme intravenously at dosages from 0.25 to $0.75 \mathrm{mg} / \mathrm{kg}$ over $30-120 \mathrm{~min}$. The last five patients who received t-PA in this study were treated on an open basis with $0.75 \mathrm{mg} / \mathrm{kg}$ over $120 \mathrm{~min}$. Only one patient in the study achieved reperfusion during the placebo infusion, and no further data regarding this patient are presented here [18]. The remaining 20 consecutive patients who received $t-P A$, three by intracoronary delivery and 17 by intravenous administration, serve as the study group. Each patient who demonstrated reperfusion was placed on an antithrombotic regimen of heparin $(1,000 \mathrm{U} / \mathrm{hr}$ ), aspirin $(315 \mathrm{mg}$ per day), dipyridamole ( $75 \mathrm{mg}$ three times per day), and nifedipine (10 $\mathrm{mg}$ four times per day) immediately after the initial catheterization.

\section{Coronary Angioplasty}

All patients with suitable coronary artery anatomy were considered for coronary artery balloon dilatation. The criteria utilized to determine suitability were 1) successful t-PA mediated coronary thrombolysis; 2) a discrete, high grade residual stenosis at the site of prior occlusion; and 3) atherosclerotic disease confined to the infarct vessel or lack of critical, diffuse disease in the noninfarct related coronary arteries. Of 13 patients who exhibited recanalization after t-PA, four patients were not considered candidates for PTCA. The reason for exclusion was severe, diffuse, multivessel disease in all four patients. Coronary angioplasty was performed in the remaining nine patients at a mean of $21.6 \mathrm{hr}$ (range $0.5 \mathrm{hr}$ to 3 days), the time dependent on cardiothoracic surgical backup availability. Angioplasty was performed via the femoral approach using USCI (Billerica, MA) guiding and dilatation catheters and guide wires. The balloon size was selected on the basis of estimated vessel size proximal to the target lesion. In the infarct vessel of each patient, the area of stenosis was dilated with 2-3 balloon inflations (range 4-11 atmospheres). Using caliper measurements, the residual lesion was quantitated as percent diameter stenosis averaging the value in two angiographic views, one in each obliquity.

\section{Evaluation of Regional Myocardial Function}

Regional left ventricular function was evaluated using serial two-dimensional echocardiography, performed prior to t-PA, throughout the infusion and for $1 \mathrm{hr}$ after its completion, and at 1 and 10 days after admission. The echocardiograms were reviewed by two observers, independently, and blinded to patient identity, the temporal sequence of study acquisition, therapy, and the effects of therapy. For analysis the myocardium was divided into seven segments, and the infarct zone was matched to the distribution of the infarct vessel, as determined by angiography. The infarct zone comprised a mean of 3.15 segments (range two to five segments) and each segment was scored using semiquantitative visual wall motion analysis. The grading utilized was -1 , dyskinesis, defined as paradoxical expansion of endocardial movement; 0 , akinesis, or absence of endocardial motion; 1, hypokinesia, defined as reduced inward motion; and 2, normal. A wall motion score index for the infarct zone was calculated 
according to a modification of the method of Heger et al [35] by averaging the scores for the two observers, summating the scores for the infarct zone segments, and dividing by the number of segments localized to this zone. This analysis was performed for the echocardiograms obtained prior to therapy and prehospital discharge, approximately 10 days after admission.

\section{Submaximal Exercise Treadmill Testing}

All patients who underwent PTCA attempts were exercised on a treadmill with 12 lead electrocardiographic monitoring prior to discharge. The target heart rate utilized was 120 beats/min and the test was stopped for symptoms of ischemia or electrocardiographic $\geqslant 1 \mathrm{~mm}$ ST segment depression in one or more leads. In one patient who developed chest pain of uncertain etiology (atypical quality without accompanying electrocardiographic changes) and another patient who had equivocal ST segment changes during exercise, repeat coronary arteriography was performed.

\section{Postdischarge Follow-Up}

The status of each patient who underwent t-PA and PTCA therapy was determined by either direct out-patient examination or via telephone communication with the patient or his attending physician.

\section{Statistical Methods}

Unless otherwise stipulated, all values are reported as mean \pm 1 standard deviation of the mean. The infarct zone wall motion indices were compared for the patient groups using a paired t-test, and intergroup differences between admission and day 10 index were tested using a one-way analysis of variance.

\section{RESULTS}

\section{Recanalization}

Reperfusion of the infarct vessel was evident in 13 out of the 20 patients (65\%) who received rt-PA. Relevant data are summarized in Table I. This occurred at 5.1 $\pm 1.1 \mathrm{hr}$ from the onset of chest pain, utilizing a dose of $43 \pm 17 \mathrm{mg}$ of rt-PA. Of

TABLE I. Patient and Therapy Characteristics*

\begin{tabular}{ll}
\hline Age & $55 \pm 5.7$ years (range 39-69 years) \\
\hline Sex & 17 male, three female \\
Time (CP to lysis) & $5.1 \pm 1.1 \mathrm{hr}$ \\
Time (CP to drug) & $4.8 \pm 1.5 \mathrm{hr}$ \\
Site of occlusion & LAD nine pts; LCx two pts; RCA nine \\
& pts \\
Dose of rt-PA & $43 \pm 17 \mathrm{mg}$ \\
Route & IV 17 pts, IC three pts \\
Successful lysis & 13 of 20 pts $(65 \%) ; 12$ of 17 pts $(71 \%)^{\mathrm{a}}$ \\
\hline *CP, chest pain; Drug, study medication; IC, intracoronary; IV, \\
intravenous; LAD, left anterior descending coronary artery; LCx, left \\
circumflex artery; lysis, coronary recanalization; pts, patients; rt-PA, \\
recombinant tissue plasminogen activator. \\
aThrombolysis with intravenous recombinant tissue plasminogen \\
activator.
\end{tabular}


those patients who received the enzyme intravenously (without the delay of a placebo infusion), 12 of 17 achieved thrombolysis. From the start of the infusion, the time to angiographic lysis was $36 \pm 9 \mathrm{~min}$. The residual lesion after successful thrombolysis was $84 \pm 6 \%$. The site of occlusion was the left anterior descending artery in nine patients, left circumflex artery in two patients, and the right coronary artery in nine patients. The infusion was not accompanied by any untoward effects in 16 patients; in four patients there was evidence of minor bleeding, from the gingiva in two patients, from the ear in one patient, and guaiac positive emesis in one patient. Six of the 20 patients had bleeding around the femoral vascular access sites either while the sheaths were in place or in small, localized hematomas after the sheaths were removed. No patient received a blood transfusion during the course of the study.

\section{Coronary Angioplasty}

PTCA was attempted in nine patients (Table II). In two patients reocclusion of the infarct vessel was noted at the time of angioplasty attempt. Both of these patients had been asymptomatic between the time of successful thrombolysis and repeat control angiography for coronary dilatation. Despite multiple attempts to cross the site of total occlusion, a guide wire could not be advanced in one patient and a $2.0 \mathrm{~mm}$ low profile dilating catheter could not successfully traverse the other patient's occlusion. In the other seven patients, PTCA was successful. A representative set of angiograms is shown in Figure 1. The residual stenosis was reduced from $84 \pm 6 \%$ to $29 \pm 7 \%$. The residual transstenotic gradient was less than $15 \mathrm{~mm} \mathrm{Hg}$ in all of these patients. No complication of the procedure occurred in any of the patients for whom the procedure was attempted. There was angiographic evidence of localized intimal dissection in four of the seven patients.

\section{Hospital Course: Clinical Outcome}

Of the patients reperfused, the seven who had successful coronary angioplasty had no evidence of reinfarction, postinfarction angina, congestive heart failure, or reocclusion or need for coronary artery bypass surgery. In the six patients who exhibited recanalization but did not undergo angioplasty (or this procedure was unsuccessful), there was evidence of reocclusion in four patients, reinfarction in one patient, postinfarction angina in three patients, and coronary artery bypass surgery was performed in three patients.

\section{Response to Exercise Testing}

Of the patients who had successful rt-PA mediated coronary thrombolysis and PTCA, five of seven had a negative submaximal graded exercise treadmill test. In two of these patients repeat coronary arteriography was performed because of either an equivocal exercise electrocardiogram or atypical chest pain, and both patients demonstrated a widely patent infarct vessel.

\section{Regional Myocardial Function}

In the seven patients reperfused and mechanically revascularized, the infarct zone wall motion index significantly improved (from $0.83 \pm 0.36$ on admission to $1.46 \pm$ 0.49 at 10 days; $P=0.01$ ) compared to those patients with successful thrombolysis only (from $0.58 \pm 0.25$ to $0.80 \pm 0.33$ at 10 days, $P=N S$ ) or those patients without recanalization (from $0.63 \pm 0.32$ to $0.54 \pm 0.42$ at 10 days, $P=N S$ ). The differ- 


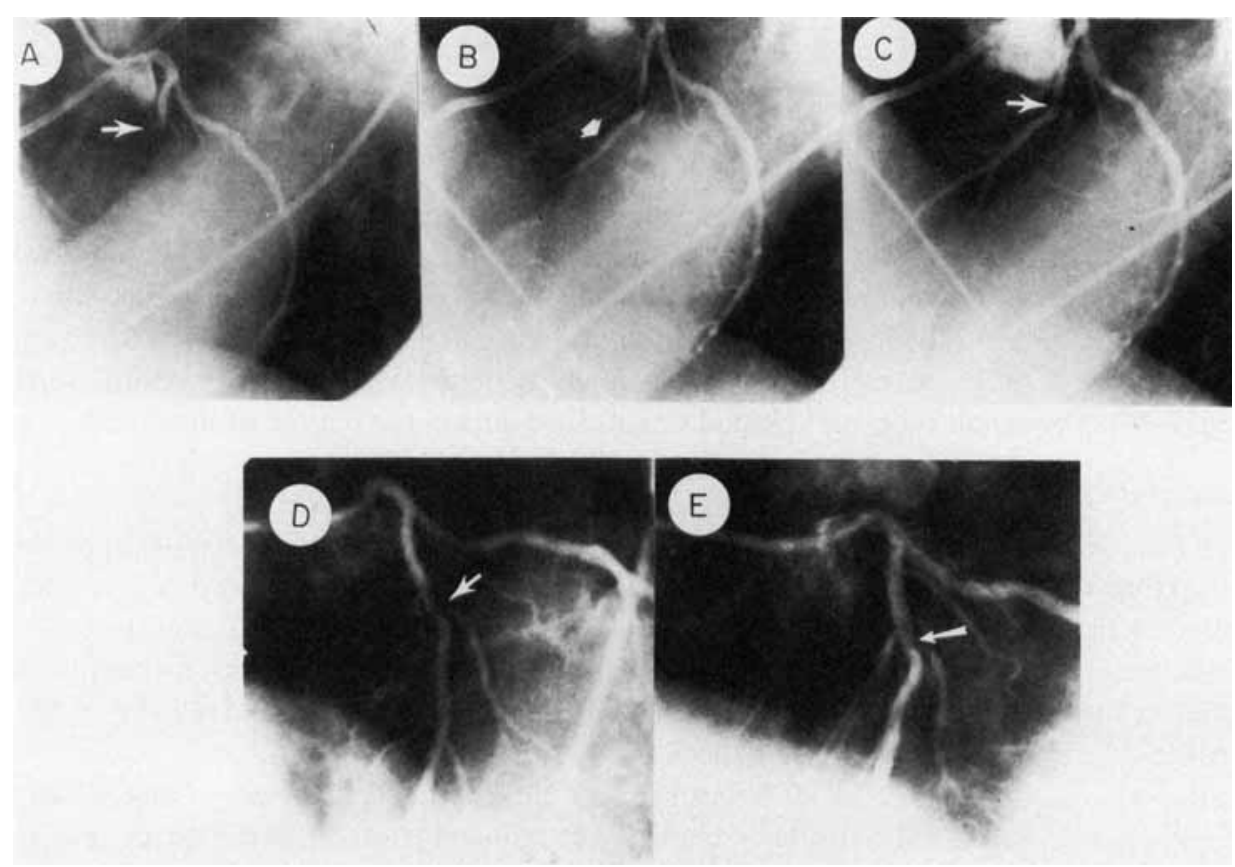

Fig. 1. Serial cineangiograms of the left anterior descending coronary artery from a study patient. A) Left anterior oblique projection shows total occlusion (arrow). B) Midway through the t-PA infusion recanalization is apparent with slow and incomplete filling of the distal vessel (arrow) and residual thrombus at the site of previous occlusion. C) Thirty minutes after completion of the infusion, a high grade residual lesion is evident (arrow). D) Just prior to angioplasty (40 h postinfarct) a persistent high grade stenosis (arrow) is apparent. E) After coronary angiography, a minimal residual lesion is shown with haziness at the site of dilatation (arrow).

ences in baseline infarct zone wall motion indices were not statistically significant (ANOVA). Further, there was significant improvement in the infarct zone index of the patient group with successful thrombolysis and PTCA compared to the other two groups $(\mathrm{F}=5.85, \mathrm{P}<0.05$, one way ANOVA; Fig. 2).

\section{Follow-Up}

One patient who had successful thrombolysis and PTCA sustained a massive stroke 2 weeks after hospital discharge. The remaining six patients in this group have returned to work and are asymptomatic at $9.4 \pm 2$ months. One patient became symptomatic with angina 7 months after hospital discharge. Coronary arteriography demonstrated restenosis $(90 \%)$ of the right coronary artery lesion and this was successfully dilated. Repeat graded exercise testing was negative and the patient is free of symptoms.

\section{DISCUSSION}

Our results demonstrate that coronary angioplasty can be performed safely and succesfully after tissue plasminogen activator thrombolytic therapy in patients with 


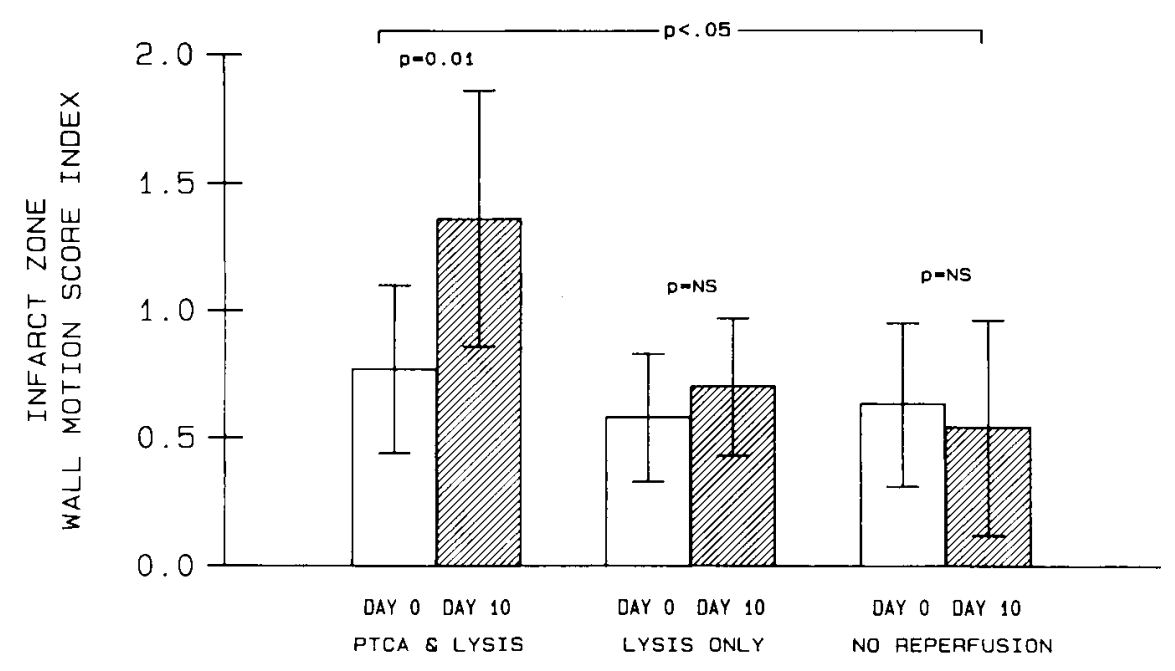

Fig. 2. Regional myocardial function on admission and at 10 days after therapy with either reperfusion with t-PA and sequential PTCA, thrombolysis only or no reperfusion. The infarct zone wall motion index (mean \pm SD) is plotted versus the time of the study for each patient group. There was significant improvement of infarct zone segmental motion only in the patient group with successful t-PA mediated thrombolysis and mechanical revascularization.

acute myocardial infarction. Although this represents a small, uncontrolled series, this combined interventional strategy was correlated with a favorable in-hospital and long-term clinical outcome as well as clear-cut improvement in regional wall motion of the infarct zone.

\section{Rationale for Combination Therapy}

The vast majority of patients with acute coronary occlusion who achieve reperfusion after thrombolytic therapy are left with a high grade stenotic lesion [36-38]. The atherosclerotic plaque narrowing has important potential consequences. First, it appears to serve as a nidus for rethrombosis, and the incidence of reocclusion is inversely correlated to the artery cross-sectional area after recanalization [37]. The propensity to reocclude may relate to the adherence of fibrin to the atherosclerotic plaque, as we have previously demonstrated to occur in an experimental atherosclerotic model after therapy with t-PA [39]. The propagation of a thrombus may thus be enhanced under conditions of reduced flow. Second, the high grade atherosclerotic lesion is usually flow-limiting, so that myocardial tissue is still "underperfused" and evaluation of function may be confounded because it is difficult to distinguish accurately infarcted versus ischemic myocardium. In this setting, the effects of coronary angioplasty may be particularly complementary and desirable by virtue of their potential to reduce the propensity for rethrombosis and provide more complete revascularization to the infarct zone.

\section{Comparison With Previous Studies}

There are several prior studies of patients with myocardial infarction that confirm the ability of PTCA to achieve a high primary success rate either after thrombolytic therapy or directly [24-34]. Most of these investigations support a diminished inci- 
TABLE II. Response to Therapy With rt-PA and PTCA*

\begin{tabular}{|c|c|c|c|c|c|c|c|c|}
\hline $\begin{array}{l}\text { Patient } \\
\text { No. }\end{array}$ & Age & Sex & Vessel & $\begin{array}{l}\text { Time to } \\
\text { lysis (hr) }\end{array}$ & $\begin{array}{c}\text { Time to } \\
\text { PTCA (hr) }\end{array}$ & $\begin{array}{c}\text { Dose } \\
\text { t-PA (mg) }\end{array}$ & Route & $\begin{array}{l}\text { Residual lesion } \\
\text { after lysis (\%) }\end{array}$ \\
\hline 1 & 69 & $\mathbf{M}$ & LAD & 4.1 & 12 & 25 & IC & 97.5 \\
\hline 2 & 40 & $\mathbf{M}$ & RCA & 5.5 & 0.6 & 40 & IV & 82.6 \\
\hline 3 & 54 & $\mathrm{~F}$ & RCA & 5.8 & 40 & 62 & IV & 86.9 \\
\hline 4 & 56 & $\mathbf{M}$ & $\mathrm{RCA}$ & 4.2 & 62 & 40 & IV & 81.7 \\
\hline 5 & 68 & F & RCA & 6.4 & 38 & 38 & IV & 81.4 \\
\hline 6 & 68 & $F$ & LAD & 6.1 & 40 & 17 & IV & 76.2 \\
\hline 7 & 68 & $\mathbf{M}$ & RCA & 4.6 & 1 & 94 & IV & 85.7 \\
\hline 8 & 39 & $\mathbf{M}$ & LAD & 6.2 & 1 & 30 & IV & 88.1 \\
\hline 9 & 53 & $\mathbf{M}$ & LAD & 3.1 & 0.75 & 62 & IV & 95 \\
\hline Total & 57.2 & $\begin{array}{l}6 \mathrm{M} \\
3 \mathrm{~F}\end{array}$ & $\begin{array}{l}4 \mathrm{LAD}, \\
5 \mathrm{RCA}\end{array}$ & $5.1 \pm 1.1$ & $21.6 \pm 23$ & $45 \pm 23$ & $\begin{array}{l}1 \mathrm{IC}, \\
8 \mathrm{IV}\end{array}$ & $83.9 \pm 5.7$ \\
\hline
\end{tabular}

${ }^{*}$ ETT, exercise treadmill test predischarge; IV, intravenous; IC, intracoronary; lysis, coronary recanalization; LAD, left anterior descending coronary artery; RCA, right coronary artery; PTCA, percutaneous transluminal coronary angioplasty; rt-PA, recombinant tissue plasminogen activator.

${ }^{\text {a }}$ Time from onset of chest pain.

${ }^{\mathrm{b}}$ In two patients, control angiography at PTCA attempt revealed total reocclusion and the procedure was unsuccessful.

dence of reocclusion when the two interventions, streptolysis and angioplasty, are combined compared to only thrombolysis. However, only two such studies were randomized $[28,34]$ and the endpoint for all has been angiographic appearance of the vessel either acutely or prehospital discharge. In a recent study, Yasuno et al [33] considered global and regional ventricular function after urokinase and PTCA and demonstrated improvement at 6 weeks postinfarct. And, in a randomized study by O'Neill et al [34], direct coronary angioplasty was superior to intracoronary streptokinase in leading to improved myocardial blood flow and left ventricular function. Prior studies of sequential thrombolysis and angioplasty therapy are summarized in Table III.

\section{Advantages of Thrombolysis With t-PA}

The key theoretical advantages of t-PA compared to first-generation lytic agents, streptokinase and urokinase, relate to its fibrin selectivity, short half-life, and lack of antigenicity. Via the intravenous route, the ability of rt-PA to dissolve coronary thrombus has been approximately $75 \%$ [18], which compares favorably to the 50 $55 \%$ efficacy rate of intravenous streptokinase $[8,40]$, and this increased rate of thrombolysis has been associated with a relative sparing of fibrinogen and absence of a systemic lytic state $[14,18]$. However, it has become clear that too high a dose of $t-$ PA may lead to similar effects as those of streptokinase by virtue of the production of free plasmin [41-43]. The short half-life of this enzyme offers particular advantage for sequential surgical or transluminal balloon coronary revascularization, since these procedures can be accomplished without the hazard of prolonged or severe bleeding. On the other hand, the short time span of fibrinolysis with t-PA may allow more acute rethrombosis in comparison with intravenous streptokinase, which at the doses cur- 
TABLE II (Continued)

\begin{tabular}{|c|c|c|c|c|c|}
\hline \multirow{2}{*}{$\begin{array}{l}\text { Residual lesion } \\
\text { after PTCA (\%) }\end{array}$} & \multirow{2}{*}{$\begin{array}{l}\text { Localized } \\
\text { dissection }\end{array}$} & \multicolumn{2}{|c|}{ Infarct wall motion index } & \multirow[b]{2}{*}{ ETT } & \multirow[b]{2}{*}{ Follow-up } \\
\hline & & Admission & Day 10 & & \\
\hline$-^{\mathrm{b}}$ & No & 0.5 & 0.66 & Not done & Successful CABG \\
\hline 35 & Yes & 1.12 & 1.4 & Negative & Asymptomatic \\
\hline 27.8 & Yes & 1.25 & 1.87 & Negative & Asymptomatic \\
\hline 36.2 & No & 0.33 & 0.83 & $\begin{array}{l}\text { Atypical } \\
\text { chest pain }\end{array}$ & $\begin{array}{l}\text { Repeat angiography- } \\
\text { patency, asymptomatic }\end{array}$ \\
\hline$-^{b}$ & No & 0.67 & 1.33 & Negative & Asymptomatic \\
\hline 19.3 & No & 0.83 & 2.0 & Negative & Asymptomatic \\
\hline 25 & No & 0.37 & 1.75 & Negative & $\begin{array}{l}\text { Restenosis at } 9 \text { months; } \\
\text { successful repeat PTCA }\end{array}$ \\
\hline 23.6 & Yes & 0.82 & 1.66 & Equivocal & $\begin{array}{l}\text { Repeat angiography- } \\
\text { patency; stroke } 2 \text { weeks } \\
\text { after discharge }\end{array}$ \\
\hline 37.2 & Yes & 1.12 & 0.75 & Negative & Asymptomatic \\
\hline $29.2 \pm 7.0$ & $\begin{array}{l}4 \text { yes, } \\
5 \text { no }\end{array}$ & $0.77 \pm 0.33$ & $1.36 \pm 0.50$ & & \\
\hline
\end{tabular}

rently utilized (750,000 to 1.5 million units) leads to at least a $24-\mathrm{hr}$ period of a systemic lytic state.

\section{Timing of Coronary Angioplasty}

In the present study, PTCA was performed either directly following thrombolysis or after transfer of the patient and/or surgical backup could be provided. It is unclear what represents the optimal timing for PTCA after coronary thrombolysis, assuming that these interventions are done sequentially. In most previous studies, coronary angioplasty was performed immediately after recanalization was established with lytic therapy. But this strategy is not readily transferable to a community hospital that is not set up for coronary angioplasty but has the necessary personnel to administer readily a safe fibrinolytic agent. Several experimental and clinical studies point toward the critical importance of time to the salvage of myocardium [44-46]. The regional wall motion improvement observed in our study did not appear to relate to the time of angioplasty, but clearly this series is too small to make any conclusion. If such a benefit can be confirmed in large, controlled trials, sequential therapy of fibrinolytic and mechanical therapy could be widely applied.

\section{Limitations}

In view of the small number of patients in this pilot study, our results must be considered preliminary and will require confirmation and replication in larger, controlled trials that are currently underway. Coronary angioplasty was not performed on a randomized basis. The selection criteria for this procedure were successful reperfusion and suitable coronary artery anatomy. Although coronary dilatation was associated with significant regional wall motion improvement, this may have been due to the favorable anatomy itself, which may correlate with subsequent functional recovery. Our results indicate that reperfused, infarct zone segments without subsequent PTCA lacked significant wall motion improvement compared to infarct regions 
TABLE III. Prior Studies of Coronary Thrombolysis and PTCA*

\begin{tabular}{lccccc}
\hline Reference & $\begin{array}{c}\text { No. } \\
\text { patients }\end{array}$ & $\begin{array}{c}\text { Lytic } \\
\text { agent }\end{array}$ & $\begin{array}{c}\text { Time of } \\
\text { PTCA (hr) }\end{array}$ & $\begin{array}{c}\text { Success } \\
(\%)\end{array}$ & $\begin{array}{c}\text { Late patency } \\
(\%)\end{array}$ \\
\hline Meyer et al [24] & 21 & SK & 1 & 81 & Not studied \\
Gold et al [25] & 28 & SK & Immediate & 71 & $55(8-14$ days $)$ \\
Hartzler et al [27] & 39 & SK & Immediate & 87 & $94(10$ days); \\
Uebis et al [28] & 25 & SK & Immediate & 96 & $79(6$ months $)$ \\
Papapietro et al [29] & 18 & SK & Immediate & 72 & $100(3$ days) \\
Kalbfleisch et al [30] & 15 & SK & Immediate & 93 & 100 (6-17 days) \\
Holmes et al [31] & 22 & SK & Immediate & 68 & Not studied \\
Schwarz et al [32] & 28 & SK & Immediate & 89 & Not studied \\
Yasuno et al [33] & 32 & UK & Immediate & 72 & 66 (42 days) \\
Pooled results & 228 & 8 SK, 1 UK & & 81 & $75(3-42$ days) \\
\hline
\end{tabular}

*SK, streptokinase; UK, urokinase; late patency, widely patent vessel at repeat angiography; time of PTCA, time after coronary thrombolytic therapy.

not reperfused. Thus, it remains possible that coronary artery dilatation was the sole factor responsible for improvement.

\section{Implications}

The exact role of coronary angioplasty in acute myocardial infarction remains unclear but there are numerous advantages that have already been observed. It appears technically preferable to administer a fibrinolytic agent immediately, allowing for the time to set up an invasive cardiology laboratory for coronary angioplasty. Recanalization of the infarct vessel would at least provide a "roadmap" for the dilatation hardware and potentially make the angioplasty procedure safer and easier. Perhaps more important, however, is the prompt restoration of flow, albeit often incomplete, with a chemical means of therapy. The time required to administer an intracoronary agent has been at least 1.5 to $2 \mathrm{hr}[1-8,10]$ from patient identification into a study protocol and would be expected to be at least this long for a PTCA procedure; the optimal timing of this procedure remains undefined. In the interval period of time, thrombolysis could be achieved. Tissue plasminogen activator has several properties that combined with coronary angioplasty may make this sequence of interventions the optimal therapy for patients with acute myocardial infarction.

\section{REFERENCES}

1. Rentrop P, Blanke H, Karsch KR, Kreuzer H: Initial experience with transluminal recanalization of the recently occluded infarct-related coronary artery in acute myuocardial infarction-comparison with conventionally treated patients. Clin Cardiol 2:92-105, 1979.

2. Khaja F, Walton JA, Brymer JF, Lo E, Osterberger L, O'Neill WW, Colfer HT, Weiss R, Lee T, Kurian T, Goldberg AD, Pitt B, Goldstein S: Intracoronary fibrinolytic therapy in acute myocardial infarction. Report of a prospective randomized trial. N Engl J Med 308:1305-1311, 1983.

3. Anderson JL, Martshall HW, Bray BE, Lutz JR, Frederick PR, Yanowitz FG, Datz FL, Klausner SC, Hagan AD: A randomized trial of intracoronary streptokinase in the treatment of acute myocardial infarctioin. N Engl J Med 308:1312-1318, 1983.

4. Rentrop KP, Feit F, Blanke H, Stecy P, Schneider R, Rey M, Horowitz S, Goldman M, Karsch K, Meilman H, Cohen M, Siegel S, Sanger J, Slater J, Gorlin R, Fox A, Fagerstrom R, Calhoun WF: Effects of intracoronary streptokinase and intracoronary nitroglycerin infusion on coronary angiographic patterns and mortality in patients with acute myocardial infarction. N Engl J Med 311:1457$1463,1984$. 
5. Leiboff RH, Katz RJ, Wasserman AG, Bren GB, Schwartz H, Varghese PJ, Ross AM: A randomized, angiographically controlled trial of intracoronary streptokinase in acute myocardial infarction. Am J Cardiol 53:404-407, 1984.

6. Kennedy JW, Ritchie JL, Davis KB, Fritz JK: Western Washington randomized trial of intracoronary streptokinase in acute myocardial infarction. N Engl J Med 309:1477-1482, 1983.

7. Anderson JL, Marshall HW, Askins JC, Lutz JR, Sorensen SG, Menlove RL, Yanowitz FG, Hagan AD: A randomized trial of intravenous and intracoronary streptokinase in patients with acute myocardial infarction. Circulation 70:606-618, 1984.

8. Spann JF, Sherry S, Carabello BA, Denenberg BS, Mann RH, McMann WD, Gault JH, Gentzler $\mathrm{RD}$, Belber AD, Maurer AH, Cooper EM: Coronary thrombolysis by intravenous streptokinase in acute myocardial infarction: Acute and follow-up studies. Am J Cardiol 53:655-661, 1984.

9. Ritchie JL, Davis KB, Williams DL, Caldwell J, Kennedy JW: Global and regional left ventricular function and tomographic radionuclide perfusion: The Western Washington intracoronary streptokinase in myocardial infarction trial. Circulation 70:867-875, 1984.

10. Mathey DG, Kuck KH, Tilsner V, Krebber HJ, Bleifeld W: Nonsurgical coronary artery recanalization in acute transmural myocardial infarction. Circulation 63:489-497, 1981.

11. Timmis GC, Gangadharan V, Ramos RG, Hauser AM, Westveer DG, Stewart J, Goodflesh R, Gordon S: Hemorrhage and the products of fibrinogen digestion after intracoronary administration of streptokinase. Circulation 69:1146-1152, 1984.

12. Verheugt FWA, Eenige MJ, Simoons ML, Hamulyak C, Van Hoogenhuyze D, De Zwaan C: Bleeding complications of intracoronary streptokinase: Assessment of risk in a randomized trial [Abstr]. Circulation 70(Suppl II):II-29, 1984.

13. Duckert F: Thrombolytic therapy. Semin Thromb Hemostas 10:87-103, 1984.

14. Van de Werf F, Ludbrook PA, Bergmann SR, Tiefenbrunn AJ, Fox KAA, De Geest H, Verstraete M, Collen D, Sobel BE: Coronary thrombolysis with tissue-type plasminogen activator in patients with evolving myocardial infarction. N Engl J Med 310:609-613, 1984.

15. Collen D, Verstraete M: Systemic thrombolytic therapy of acute myocardial infarction? Circulation 68:462-465, 1983.

16. Korninger C, Matsuo O, Suy R, Stassen JM, Collen D: Thrombolysis with human extrinsic (tissuetype) plasminogen activator in dogs with femoral vein thrombosis. J Clin Invest 69:573-580, 1982.

17. Collen D, Stassen JM, Verstraete M: Thrombolysis with human extrinsic (tissue-type) plasminogen activator in rabbits with experimental jugular vein thrombosis. Effect of molecular form and dose of activator, age of the thrombus, and route of administration. J Clin Invest 71:368-376, 1983.

18. Collen D, Topol EJ, Tiefenbrunn AJ, Gold HK, Weisfeldt ML, Sobel BE, Leinbach RC, Brinker JA, Ludbrook PA, Yasuda I, Bulkley BH, Robison AK, Hutter AM Jr, Bell WR, Spadaro JJ Jr, Khaw BA, Grossbard EB: Coronary thrombolysis with recombinant human tissue-type plasminogen activator: A prospective, randomized, placebo-controlled trial. Circulation 70:1012-1017, 1984.

19. Bergmann SR, Fox KAA, Ter-Pogossian MM, Sobel BE: Clot-selective coronary thrombolysis with tissue-type plasminogen activator. Science 220:1181-1183, 1983.

20. Flameng W, Van de Werf F, Vanhaecke J, Verstraete M: Coronary thrombolysis and infarct size reduction after intravenous infusion of recombinant tissue-type plasminogen activator in nonhuman primates. J Clin Invest 75:84-90, 1985.

21. Collen D, Staasen JM, Verstraete M: Thrombolysis with human extrinsic (tissue-type) plaminogen activator in rabbits with experimental jugular vein thrombosis. J Clin Invest 71:368-376, 1983.

22. Weimar W, Stibbe J, Van Seyen AJ, Billau A, De Somer P, Collen D: Specific lysis of an ileofemoral thrombus by administration of extrinsic (tissue-type) plasminogen activator. Lancet 2:1018-1020, 1981.

23. Gold HK, Fallon JT, Yasuda T, Leinbach RC, Khaw BA, Newell JB, Guerrero JL, Vislosky FM, Hoyng CF, Grossbard E, Collen D: Coronary thrombolysis with recombinant tissue-type plasminogen activator. Circulation 70:700-770, 1984.

24. Meyer J, Merx W, Schmitz H, Erbel R, Kiesslich T, Dorr R, Lambertz H, Bethge C, Krebs W, Bardos P, Minale C, Messmer BJ, Effert S: Percutaneous transluminal coronary angioplasty immediately after intracoronary streptolysis of transmural myocardial infarction. Circulation 66:905913, 1982.

25. Gold HK, Cowley MJ, Palacios IF, Vetrovec GW, Akins CW, Block PC, Leinbach RC: Combined intracoronary streptokinase infusion and coronary angioplasty during acute myocardial infarction. Am J Cardiol 53:122C-125C, 1984. 
26. Gold HK, Leinbach RC, Palacios IF, Yasuda T, Block PC, Buckley MJ, Akins CW, Daggett WM, Austen WG: Coronary reocclusion after selective administration of streptokinase. Circulation 68: I-50-I-54, 1983.

27. Hartzler GO, Rutherford BD, McConahay DR: Percutaneous transluminal coronary angioplasty: Application for acute myocardial infarction. Am J Cardiol 53:117C-121C, 1984.

28. Uebis R, Essen RV, Merx W, Schmidt WG, Emons HP, Effert S: Combined medical and mechanical recanalization versus superselective streptokinase alone: Reperfusion rate and time of occlusion [Abstr]. Circulation 70:II-329, 1984.

29. Papapietro SE, MacLean WAH, Stanley AWH, Hess RG, Corley N, Arciniegas JG, Cooper TB: Percutaneous transluminal coronary angioplasty after intracoronary streptokinase in evolving acute myocardial infarction. Am J Cardiol 55:48-53, 1985.

30. Kalbfleisch J, Friedman M, Slagle R, Brewer D, McEntee W, Roye A, Ross W, Hawkins H, Conrad L, Ong YSE: A randomized trial of immediate coronary angioplasty following intracoronary thrombolysis in acute myocardial infarction [Abstr]. J Am Coll Cardiol 3:576, 1984.

31. Holmes DR, Nishimura RA, Vlietstra RE, Smith HC, Reeder GS, Bove AA, Cheseboro JH: Percutaneous transluminal coronary angioplasty (PTCA) during evolving acute myocardial infarction(abstr). J Am Coll Cardiol 3:577, 1984.

32. Schwarz F, Schuler G, Hofman M, Manthey J, Mehmel HC, Kubler W: Thrombolysis in acute myocardial infarction: improved results by use of PTCA [Abstr]. Circulation 68:III-140, 1983.

33. Yasuno M, Saito Y, Ishida M, Suzuki K, Endo S, Takahashi M: Effects of percutaneous transluminal coronary angioplasty: Intracoronary thrombolysis with urokinase in acute myocardial infarction. Am J Cardiol 53:1217-1220, 1984.

34. O'Neill WW, Lai PY, Gangadharan V, Bourdillon PD, Ramos RG, Laufer N, Walton JA Jr, Linert DP, Timmis GC, Pitt B: Preliminary report of a randomized, prospective clinical trial of intracoronary streptokinase versus coronary angioplasty therapy of acute myocardial infarction [Abstr]. J Am Coll Cardiol (in press), 1985.

35. Heger JJ, Weyman AE, Wann S, Rogers WE, Dillon JC, Feigenbaum H: Cross-sectional echocardiographic analysis of left ventricular asynergy in acute myocardial infarction. Circulation 61:1113$1124,1980$.

36. Swan HJC: Thrombolysis in acute myocardial infarction: Treatment of the underlying coronary artery disease. Circulation 66:914-916, 1982.

37. Harrison DG, Ferguson DW, Collins SM, Skorton DJ, Ericksen EE, Kioschos JM, Marcus ML, White CW: Rethrombosis after reperfusion with streptokinase: Importance of geometry of residual lesions. Circulation 69:991-999, 1984.

38. Lee G, Row RI, Takeda P, Joe P, De Maria AN, Amsterdam EA, Lui H, Dietrich P, Lee K, Mason DT: Importance of follow-up medical and surgical approaches to prevent reinfarction, reocclusion, and recurrent angina following intracoronary streptokinase in acute myocardial infarction. Am Heart J 104:921-924, 1982.

39. Topol EJ, Ciuffo AA, Pearson TA, Dillman J, Builder S, Brossbard E, Weisfeldt ML, Bulkley BH: Thrombolysis with recombinant tissue plasminogen activator in atherosclerotic, thrombotic occlusion. J Am Coll Cardiol 5:85-91, 1985.

40. Laffel GL. Braunwald E: Thrombolytic therapy. A new strategy for the treatment of acute myocardial infarction. N Engl J Med 311:710-717, 1984.

41. Sobel BE, Gross RW, Robison AK: Thrombolysis, clot selectivity and kinetics. Circulation 70:160$164,1984$.

42. Tiefenbrunn AJ, Robsion AK, Kurnik PB, Ludbrook PA, Sobel BE: Clinical pharmacology in patients with evolving myocardial infarction of tissue-type plasminogen activator produced by recombinant DNA technology. Circulation 71:110-116, 1984.

43. Topol EJ, Bell WR,Brinker JA, Gottlieb SO, Brin KP, Collen D: Thrombolysis with recombinant tissue-type plasminogen activator: paradoxical in vivo and in vitro effects [Abstr]. Circulation 70 : II-365, 1984.

44. Reimer KA, Lowe, Rasmusses MM, Jennings RB: The wavefront phenomenon of ischemic cell death. 1. Myocardial infarct size vs. duration of coronary occlusion in dogs, Circulation 56:786794, 1977.

45. Reimer KA, Jennings RB: The "wavefront phenomenon" of myocardial ischemic cell death. II. Transmural progression of necrosis within the framework of ischemic bed size (myocardium at risk) and collateral flow. Lab Invest 40:633-644, 1979.

46. Schwarz F, Schuler G, Katus H, Hofmann M, Manthey J, Tillmans H, Mehmel HC, Kubler W: Intracoronary thrombolysis in acute myocardial infarction: Duration of ischemia as a major determinant of the results after recanalization. Am J Cardkol 50:933-937, 1982. 